\title{
Effect of Shapes, Binders and Densities of Faecal Matter - Sawdust Briquettes on Ignition and Burning Times
}

Peter Aguko Kabok ${ }^{1^{*}}$, Daudi M Nyaanga², Jesca Makena Mbugua ${ }^{2}$ and Reinilde Eppinga ${ }^{3}$

${ }^{1}$ Jaramogi Oginga Odinga University of Science and Technology, University in Bondo, Kenya

${ }^{2}$ Egerton University, Public University in Nioro, Kenya

${ }^{3}$ Nakuru County Sanitation Programme /Nakuru Water and Sanitation Services Company Ltd, Kenya

\begin{abstract}
Wood fuels are a major source of energy in the developing world whose sustainability is diminishing in forest cover and production increases in demand due to rising population. Alternative environmentally friendly accessible sources of energy for households are therefore a necessity. These include faecal matter, forest and agricultural residues that are convertible into briquettes. There source will depend on availability, impact on environment, renewability and energy content. The benefit of briquettes arises from near equal mass balance of carbon dioxide demand by photosynthesis in the atmosphere to the amount released during combustion. Briquetting thus need designed agglomeration machines and understanding of the engineering properties. The parameters density and shape have effect on combustion and performance characteristics hence should be determined. The research thus focused on spherical, triangular and cylindrical shapes and densities of $600 \mathrm{~kg} / \mathrm{m}^{3}, 700 \mathrm{~kg} / \mathrm{m}^{3}$ and $800 \mathrm{~kg} / \mathrm{m}^{3}$ on ignition and burning time. Carbonization of faecal matter and sawdust with binders was the activities. There was significant difference on ignition time on shapes and densities and none on burning times with shapes and binders. The average ignition time ranged from 2.7 to 3.7 minutes irrespective of shapes and binders. The average burning time ranged from 18 to 26 minutes for molasses and starch bonded cylindrical briquettes. The spherical briquettes had the least ignition time of 2.7 minutes. Packing ratio, evenly distributed air spaces, higher volatile matter in binder, porosity due density advantaged the spherical briquettes.
\end{abstract}

Keywords: Carbonization; Faecal-sawdust-briquettes; Densities; Shapes; Ignition and burning time

\section{Introduction}

Interest is growing in renewable energy due to increasing worldwide concern regarding environmental impacts and need for alternative energy supplies. Though, the forested area in Kenya has declined from independence and fuel wood is still being widely used in households for cooking, heating and lighting. It supplied $89 \%$ and $7 \%$ rural and urban household energy respectively in the year 2000 [1]. There are also other materials such as agricultural residues that can still be utilized to reduce the consumption of wood fuel blamed partly in some areas as a factor of deforestation [2]. Hence, conversion of raw materials that have challenges in disposal such as sawdust and faecal matter to sources of energy for households needs proper understanding of the engineering properties and techniques for conversion. Biomass in consideration thus qualifies as a feedstock for agglomeration due to its factors of availability, composition, low moisture and ash content [3].

Agglomeration is the process of production of a compact product from loose raw material into high density fuel briquettes [2], categorized into pressure and non-pressure. Pressure agglomeration technology uses mechanical compression to form a homogeneous dense product and options include; compaction or granulation, briquetting or densification using screw extruders or mechanical and hydraulic piston presses [4]. Choice of the agglomerator depends on the equipment capabilities, desired product for instance type, shape, binder properties and raw material characteristics. The non-pressure agglomeration technology is a tumbling process where the material grows spherically into a compact product depended on the desired size using a pan or disc pelletiser, rotary drum agglomerator or drum granulator [5]. The benefit is briquettes of uniform size and shape which are easily handled, stored and transported using existing equipment [6]. Agglomerates are then tested to ascertain their suitability as a source of energy.

Attempts have been on densifying various agricultural residues into briquettes but few studies have been towards understanding effect of briquette shapes and densities on performance characteristics. On the other hand, and according to Olorunnisola [7], briquettes made using starch produce less ash, burn faster and more efficiently than those made using clay. Gachuri [8], also indicates that the commonly used binders are starch from corn, cassava, sugarcane molasses, and cow dung. Altun et al., [9] too notes that the binder types and amount do have substantial effects on the combustion of briquettes.

The easiness of the briquettes to ignite leads to proportionate increase in the flame length [10]. The ignition time of the composite faecal matter-sawdust briquettes was lower compared to coal briquettes which took 4.8 minutes, charcoal 7-10 minutes [11] and higher than water hyacinth briquettes in which ignition time was 1-2 minutes [12]. Therefore, the faecal matter-sawdust briquettes performed better as compared to charcoal and coal.

\section{Materials and Methods}

\section{Raw material preparation}

Domestic sludge was discharged from exhauster trucks into drying beds in a greenhouse to dry for two weeks. Once dried to $10 \%$ moisture content, it was carbonized in a drum kiln. Using a weighing balance,

"Corresponding author: Kabok P. Aguko, Jaramogi Oginga Odinga University of Science and Technology, University in Bondo, Kenya, Tel: + 0540346828; E-mail: kabpaguko@yahoo.com

Received March 03, 2018; Accepted June 13, 2018; Published June 21, 2018

Citation: Kabok PA, Nyaanga DM, Mbugua JM, Eppinga R (2018) Effect of Shapes, Binders and Densities of Faecal Matter- Sawdust Briquettes on Ignition and Burning Times. J Pet Environ Biotechnol 9: 370. doi: 10.4172/2157-7463.1000370

Copyright: (c) 2018 Kabok PA, et al. This is an open-access article distributed under the terms of the Creative Commons Attribution License, which permits unrestricted use, distribution, and reproduction in any medium, provided the original author and source are credited. 
$40 \mathrm{~kg}$ of dry faecal matter was measured and poured in the drum kiln. The fireplace of the kiln was charcoal filled, sprinkled with $200 \mathrm{ml}$ of paraffin and lit by a matchstick. The air intake ports and exhaust vent were opened to draw in enough oxygen for firing for 20 minutes. The ports were then closed and the vent sealed for carbonization to take place for 2 hours. A thermometer was mounted on the side of the kiln $10 \mathrm{~cm}$ from the top to monitor the temperatures.

Sawdust was collected from the saw mills in Nakuru Town, and then dried in greenhouse beds for two days to a moisture content of about $10 \%$. The sawdust was passed through a $2.8 \mathrm{~mm}$ screen to remove large wood shavings. Using a spring balance, $40 \mathrm{~kg}$ of sawdust was weighed and carbonized in a half open drum for 1 hour. Carbonized sawdust was reduced into small particle sizes by a hammer mill. The carbonized sawdust and faecal matter was hammer milled to small particle sizes of about $1 \mathrm{~mm}$ and mixed in a 1:1 ratio by volume. The binder amount added was $10 \%$ by weight of each replication.

\section{Briquetting}

Shape preparation: A $40 \mathrm{~mm}$ internal diameter cylindrical mold was made by drilling through a cylindrical mild steel bar of $75 \mathrm{~mm}$ diameter and $100 \mathrm{~mm}$ length using a lathe machine. The mold was perforated at about one third of the height to allow water to drain during briquetting as recommended by Dahlam et al. (2001). Polishing was done by fine emery paper to attain a smooth internal surface. Equivalently, an equilateral triangular mold of $40 \mathrm{~mm}$ height and 46 $\mathrm{mm}$ on the sides was prepared by welding to produce briquettes of the same size as the cylindrical briquettes. The dies were slightly smaller than the molds to reduce friction force during briquetting.

Drum granulation: Twenty kilograms of mixed ratio faecal matter and sawdust were weighed using a spring balance and poured into the drum granulator. The binding agent was then sprinkled as the drum rotated until the granules grew in size to $40 \mathrm{~mm}$ diameter. Once formed, the granulator was turned off and the spherical briquettes were spread in greenhouse beds to dry to a moisture content of $8 \%$ on wet basis. The briquettes were then sampled for analysis.

Hydraulic pressing: Fifty grams of carbonized faecal matter and sawdust were weighed, mixed with a binder and hand-fed into the molds. The mixture was compacted to form briquettes of different shapes (cylindrical and triangular) using a hydraulic press and held for 5 minutes as recommended [13]. Using the cylindrical mold, briquettes of densities 600,700 and $800 \mathrm{~kg} / \mathrm{m}^{3}$ were produced by the hydraulic press and dried in a greenhouse to a moisture content of $8 \%$. The briquettes were sampled and tested for ignition and burning time.

Water boiling test: Water boiling tests (WBT) were carried out in a controlled environment without wind but well ventilated to determine the performance of the fuel and stove. The test consists of high power (cold start and hot start) and low power (simmering) phases. The parameters determined and maintained during the WBT include; local boiling point confirmed for an altitude using a Global Positioning System (GPS) hand gadget, volume of water, weight of cook stove, ash tray and pot. Other equipment includes a small shovel for removing hot briquettes from the stove, tongs for handling briquettes, heat resistance gloves and a wood fixture for holding the thermometer probe in water. The local boiling point was determined from equation 1 .

$$
\mathrm{T}_{b}=\left(100-\frac{\mathrm{h}}{300}\right)^{0} C
$$

Where $\left(T_{b}\right)$ is local boiling temperature and $(h)$ altitude in meters.
Only the high power cold start phase was conducted in determination of ignition and burning time of the briquettes.

\section{Firing briquettes for water boiling test}

In the high power cold start phase, the cook stove temperature is equal to room temperature. Two liters of water at room temperature were poured into a pot and the briquettes stacked in the cook stove combustion chamber. Initial water temperature was determined using a digital thermometer at a depth of about $1 \mathrm{~cm}$ above bottom of the pot. The initial weight of the pot with water and cook stove with briquettes were determined using a weighing balance of $1 \mathrm{~g}$ accuracy. One gram of "moto sawa" assumed to be about $2 \mathrm{~g}$ of briquettes [14], was poured on the ash tray and lit. Briquettes were allowed to kindle and ignition time noted using a stop watch. Once the briquettes ignited, the pot with water was placed on the cook stove, starting and stopping time was recorded when the water reached the boiling point of $94^{\circ} \mathrm{C}$. Final water temperature, weight of pot with remaining water, weight of cook stove with remaining briquettes after shaking to allow the ash to fall on the ash tray, weight of ash and time to boil were recorded. Later, the characteristics were determined.

\section{Ignition and burning time}

Ignition time is the average time taken to light the briquettes [11]. It was determined and recorded using a stop watch. Three replications of each shape were done and average time determined. Burning time is the average time taken for the briquettes to burn into ash after ignition until the water boiled [11]. It was determined and recorded using a stop watch for each of the three replications.

\section{Results and Discussion}

\section{Effect of shape and binder on ignition and burning time}

Ignition time is the average time required to ignite the composite briquettes. It is affected by the amount of volatile matter and the surface area of the briquettes exposed to the airflow. The base area of briquettes on the combustion mesh exposed to air flow was $117.32 \mathrm{~cm}^{2}, 115.92$ $\mathrm{cm}^{2}$ and $100.56 \mathrm{~cm}^{2}$ for spherical, triangular and cylindrical briquettes. The more the surface area exposed to air the less the ignition time was required. Spherical briquettes had the lowest ignition time of 2.7 minutes as shown in Figure 1.

There was a significant difference $(\mathrm{P}>0.05)$ in the ignition time for different shapes and binders. Cylindrical shaped briquettes had the longest (3.5 minutes) time while triangular and spherical shapes had ignitions of 2.9 minutes and 2.7 minutes respectively. The reason for the undesirable longer ignition time for cylindrical shapes could be partly attributed to low air spaces in between the briquettes due the higher packing factor thus restricting air flow and oxygen supply. Molasses bonded briquettes had least time compared to starch bonded briquettes because these have more volatile matter. However, in terms of smoke assessed by visual observation, molasses had the least which compares well with the results by Rotich [11].

The burning time which is the duration taken to bring a certain amount of water to boiling is influenced by volatile matter, porosity and biomass of the fuel. Different shapes of briquettes created different air spaces between which allowed the air to circulate. Packing ratio is the volume of briquettes to the volume of the combustion chamber of the briquettes. Briquettes that fitted the combustion chamber were 24 , 21 and 22 with a packing ratio of $0.819,0.695$ and 0.760 for spherical, triangular and cylindrical briquettes, respectively. By maintaining the 


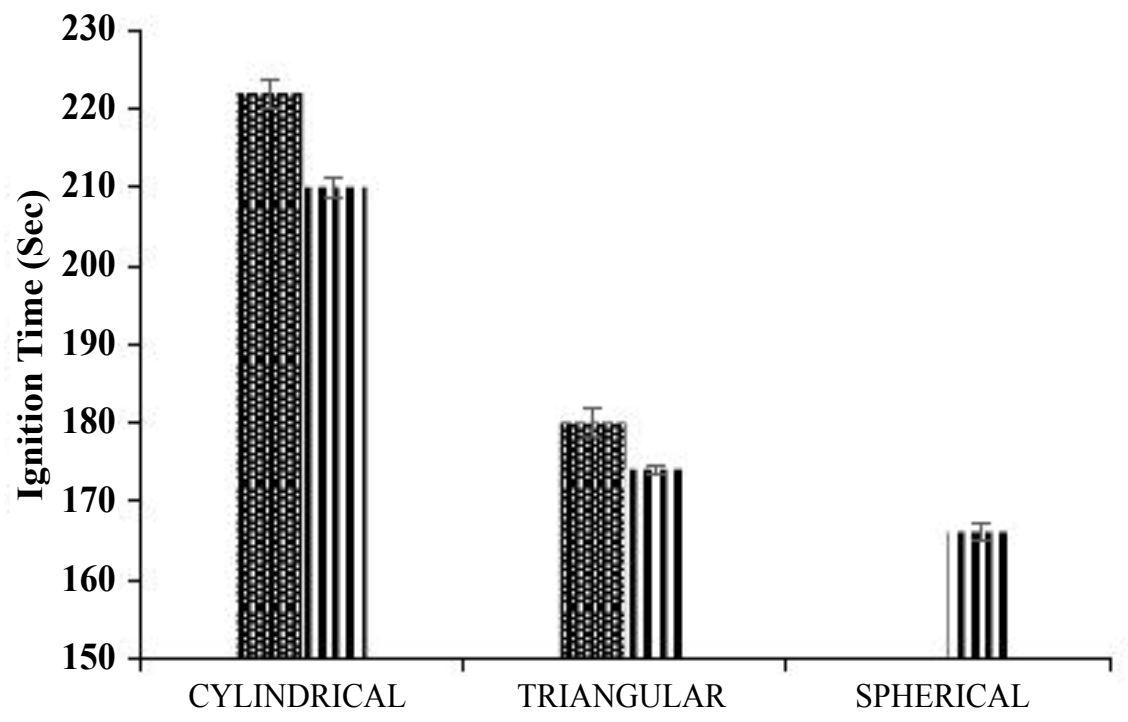

细 starch

II molasses

\section{Shapes of faecal matter - sawd ust (1:1) briqutttes}

Figure 1: Effect of briquettes shapes on ignition time.

number of briquettes at 21 for all shapes, the packing ratio was 0.695 , 0.717 and 0.726 for triangular, spherical and cylindrical briquettes. Triangular briquettes had lower packing ratio than spherical but the air spaces were not as evenly distributed as those of spherical. This led to faster ignition and burning rate of spherical briquettes than triangular briquettes leading to less burning time as shown in Figure 2.

The shape and binder of the briquettes did not result in any significant difference on the burning time (averaging 17 minutes) for the cylindrical, triangular and spherical composite briquettes of the same density. This could be because the calorific value of the fuel was the same as the briquettes were of the same materials. Air spaces between cylindrical briquettes were less compared to triangular and spherical briquettes which led to more ignition and burning time. The results agree with previous studies by Onuegbu et al. [15] which showed that packing of briquettes in the combustion chamber of the cook stove influenced air flow in between the fuel surfaces that affected the ignition and burning time. Triangular and spherical briquettes had more air spaces in between the briquettes which allowed more air flow leading to more surface area being in contact with the oxygen. The base area (packing ratio), evenly distributed air spaces, higher volatile matter in binder, porosity guided by density were an advantage in spherical briquettes compared to cylindrical and triangular briquettes. This led to faster ignition and burning rate of molasses bound spherical briquettes. Due to uniform size and shape the spherical briquettes are easily handled, stored, transported and produced by existing equipment.

\section{Effect of binder and density on ignition and burning time}

Density is an indicator of the energy concentration of a fuel. High energy density is desirable in terms of handling, transportation, storage and combustion of the fuel. Only cylindrical briquettes of different densities were considered in determination of the time taken to ignite the briquettes. The results as in Figure 3 show that molasses bonded briquettes had a significantly lower ignition time than starch; this could be attributed to higher volatile matter content in the former. The results show that the lower the briquette density, the lower the time required to ignite. The ignition time was $3.5,3.8$ and 4.0 minutes for briquettes with densities of 600,700 and $800 \mathrm{~kg} / \mathrm{m}^{3}$, respectively.

The size of the briquettes was constant but the density and mass of the carbonized materials varied. The higher density, the more the mass. Composite briquettes with lower density were less compacted than those with high density which means that cylindrical briquettes at $600 \mathrm{~kg} / \mathrm{m}^{3}$ had more air pores as compared to $800 \mathrm{~kg} / \mathrm{m}^{3}$. The air pores allowed the oxygen to percolate into the briquettes leading to combustion process as less time was required to ignite the briquettes. The results agree with the findings of Abdulrasheed et al. [16] that briquettes with low compaction have low density and burn faster than those of higher compaction. It was also observed that the flame propagation decreased with increase in density due to decrease in porosity and low oxygen penetration into the fuel agreeing with Ajayi and Lawal [17] and Davies and Abolude [12] who observed that increase in compaction pressure reduces the void spaces of the briquettes as particles are forced closer to one another causing elongation of the ignition time. The optimum density for composite briquettes with respect to the time required to ignite, was therefore the lowest density of $600 \mathrm{~kg} / \mathrm{m}^{3}$.

The results as in Figure 4 show that the burning duration increased with increase in density. The average burning time was not significantly different but varied between 18-23 minutes and 20-26 minutes for molasses and starch bonded briquettes, respectively. However, the effect of density on burning time was significant. Increase in density led to increase in mass which resulted into more ash formation during the combustion inhibiting percolation of oxygen into the fuel. The ash formed decreases the burning rate and increases the burning time comparing well with arguments by Abdulrasheed et al. [16] and Zaror and Pyle [18] who note that an increase in density reduces the porosity thus decreasing the burning rate which affects the burning time. Molasses is more volatile than starch which resulted to less burning time of briquettes compared to starch, though the difference was not significant. 


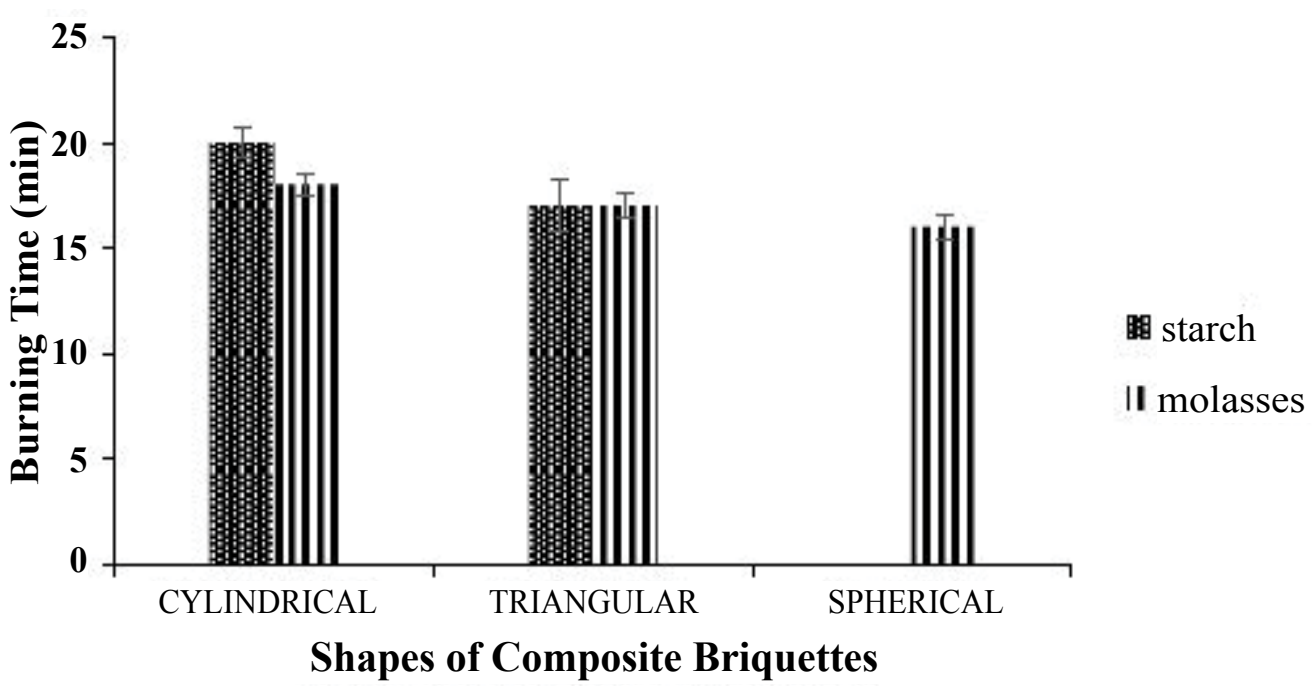

Figure 2: Effect of briquette shapes on burning time.

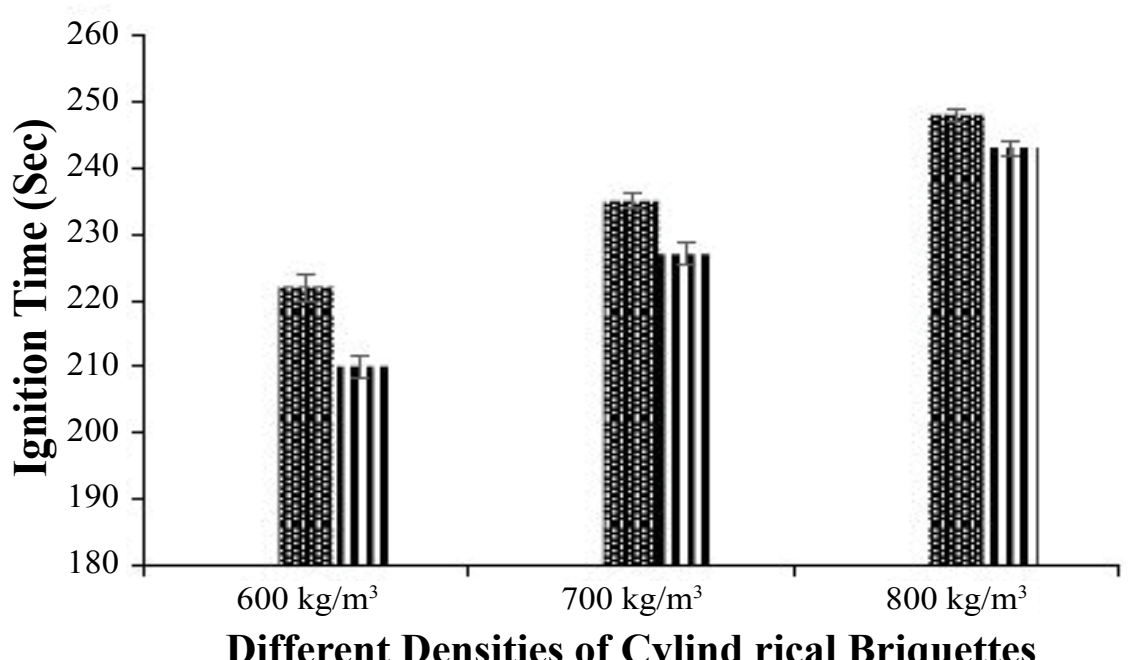

Starch

Molasses

Figure 3: Effect of briquettes densities on ignition time.

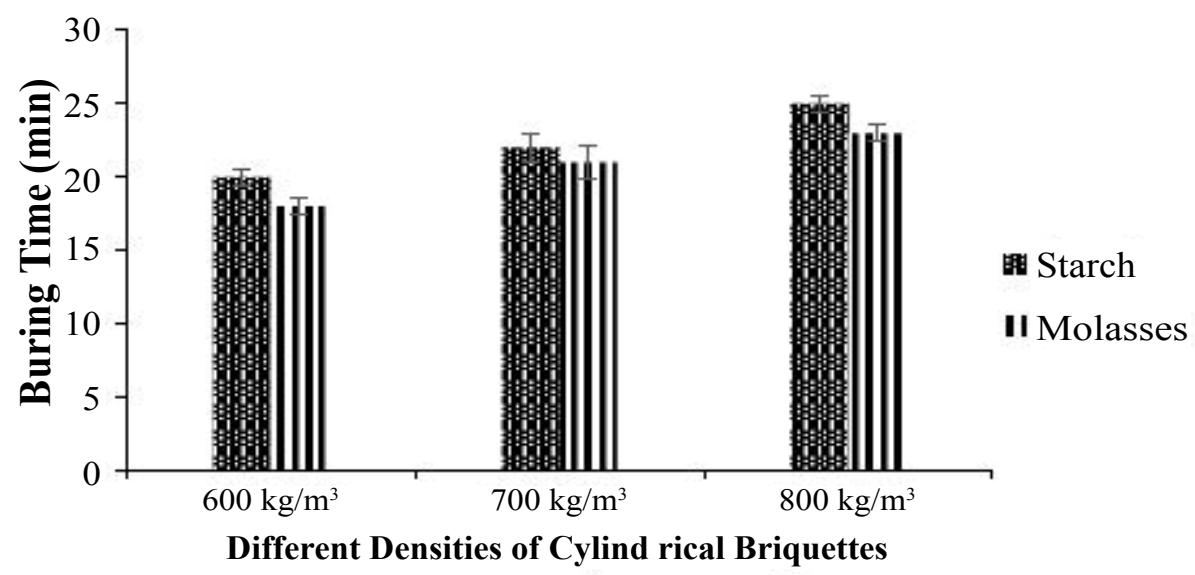

Figure 4: Effect of briquettes densities on burning time. 
Citation: Kabok PA, Nyaanga DM, Mbugua JM, Eppinga R (2018) Effect of Shapes, Binders and Densities of Faecal Matter- Sawdust Briquettes on Ignition and Burning Times. J Pet Environ Biotechnol 9: 370. doi: 10.4172/2157-7463.1000370

\section{Conclusion and Recommendations}

The study examined the ignition and burning time of carbonized faecal matter-sawdust briquettes using molasses and starch as binding agents. The ignition time was affected by shapes and densities of the briquettes. The burning time of briquettes increased with increase in density but was not significantly influenced by the binders (molasses and starch) and briquette shapes. Molasses is suggested a better option compared to starch as it is an easily available, has less smoke and a byproduct of sugar processing while starch (cassava) can be used but is a source of food. Briquettes with lower density $\left(600 \mathrm{~kg} / \mathrm{m}^{3}\right)$ were easier to ignite but had a shorter burning time while higher density briquettes $\left(800 \mathrm{~kg} / \mathrm{m}^{3}\right)$ posted reverse results. Preliminarily, the longer the burning time, the better the briquette, it is herein inferred that higher density briquettes and shapes that reduce packing factor and increase air flow rate (spherical rather than cylindrical or triangular) are better as energy fuels. Additional studies should be on increased process efficiency, acceptability of faecal matter briquettes, marketing strategies and commercial viability.

\section{Acknowledgments}

This research is part of a partnership between Nakuru County Sanitation Programme (NCSP)/ Nakuru Water and Sanitation Services Company Ltd. (NAWASSCO) and Egerton University. NCSP is a European Union co-funded programme implemented by NAWASSCO with the support of the Nakuru County government, Umande Trust, SNV Netherlands Development Organisation and Vitens Evides International. The research benefitted from the Aqua for all managed VIA Water fund and University of Nairobi laboratories. The authors gratefully acknowledge use of the services and facilities of the aforementioned institutions. Also appreciated are; J. Irungu, K. Wanjala and K. Nyandeje for their technical support in the briquetting process.

\section{References}

1. International Institute for Environment and Development (2010) Biomass energy in Kenya. Nairobi, Kenya.

2. Shekhar N (2011) Popularisation of biomass briquettes - A means for sustainable rural Development. As J Manag Res : 458-473.

3. Grover P, Mishra K (2006) Biomass briquetting technology and practices. RWEDP Home publications: Field Document 46, Chapter 1.
4. Grover P, Mishra SK (1996) Biomass briquetting: Technology and practices. FAO Regional Wood and Energy Development Programme in Asia, Bangkok, Thailand.

5. Bowden GB (2016) Granulation of biochar for soil amendment. Master of Engineering Science in Chemical and Biochemical Engineering. University of Western Ontario, London, Ontario, Canada.

6. Karunanithy C, Wang YK, Pugalendhi S (2012) Physiochemical characterization of briquettes made from different feedstock. Biotechnol Res Int 2: 1-12.

7. Olorunnisola AO (2007) Production of fuel briquettes from waste paper and coconut husk admixtures. Ag Eng Int 9: 1-15.

8. Gachuri WG (2015) Optimising the utilisation of sawdust of eucalyptus tree species. A fuel tea industry. Master of Science Degree in Environmental and Biosystems Engineering. University of Nairobi, Nairobi.

9. Altun NE, Hicyilmaz C, Bagci A (2003) Combustion characteristics of coal briquettes: Thermal features. Energy Fuels 17: 1266-1276.

10. Loo SV, Koppejan J (2008) The Handbook of Biomass Combustion and Cofiring. Earthscan, London.

11. Rotich K (1998) Carbonization and briquetting of sawdust for use in domestic cookers. Thesis, Department of Agricultural Engineering, University of Nairobi, Kenya.

12. Davies RM (2013) Ignition and burning rate of water hyacinth briquettes. J Sci Res Rep 2: 111-120.

13. Onaji P, Siemons R (2003) Production of charcoal briquettes from cotton stalks in Malawi: methodology for feasibility studies using experiences in Sudan. Biomass Bioenergy 4: 199-211.

14. Ward BJ (2009) Human fecal biochar briquettes from the sol-char toilet for use as a solid fuel in the developing world. University of Colorado at Boulder, Pro Quest Dissertations.

15. Onuegbu TU, Ekpunobi UE, Ogbu IM, Ekeoma MO, Obumselu FO (2011) Comparative studies of ignition time and water boiling test of coal and biomass briquettes blend. Int J Rec Res App Stud 7: 153-159.

16. Abdulrasheed A, Aroke UO, Ibrahim M (2015) Compression pressure effect on mechanical \& combustion properties of sawdust briquette using styrofoam adhesive as binder. Am J Eng Res 4: 205-211.

17. Ajayi OA, Lawal GT (1995) Some quality indicators of sawdust/palm oil sludge briquettes. J Ag Eng Tech 3: 55-65.

18. Zaror A, Pyle D (2002) The pyrolysis of biomass. A general review. Indian Academy of Sciences Section C: Engineering Sciences. 